\title{
Pectinase Production with Waste Materials by Local Water Isolate of Aspergillus fumigatus Strain 2101 and Purification and Characterization of the Enzyme
}

\author{
Yerel Su İzolatı Aspergillus Fumigatus 2101 Suşu Tarafından Atık \\ Malzemeler ile Pektinaz Üretimi ve Enzimin Saflaştırılması ve \\ Karakterizasyonu
}

Research Article

Hacer Yamancı', Kader Poturcu', İsmail Özmen'*, Hacı Halil Bıyık ${ }^{2}$

'Department of Chemistry, Suleyman Demirel University, Isparta, Turkey.

2Department of Biology, Adnan Menderes University, Aydın, Turkey.

\section{A B S TR ACT}

\begin{abstract}
n this study, pectin lyase (PL) was obtained from Aspergillus fumigatus strain 2101 which was isolated from local water sources. PL was purified using ammonium sulphate precipitation, gel filtration and ion-exchange chromatography. After these purification steps, 12.4 purification fold was obtained. The optimum $\mathrm{pH}$ and temperature of $\mathrm{PL}$ were 8.0 and $40^{\circ} \mathrm{C}$ at 70 min, respectively. The molecular weight of $\mathrm{PL}$ was $11.5 \mathrm{kDa}$. Maximum $\mathrm{PL}$ activity was obtained with fruit pulps in submerged culture medium. Stability assays showed that the PL was stable till 20 months at $4^{\circ} \mathrm{C}$. The highest PL activity was obtained using citrus pectin as carbon source. $\mathrm{PL}$ was strongly activated by $\mathrm{FeSO}_{4}, \mathrm{FeCl}_{3}$ and ascorbic acid.
\end{abstract}

Key Words

Pectin lyase, Aspergillus, chromatography, inhibition, ions.

\section{ÖZET}

u çalışmada, pektin liyaz (PL) yerel su kaynaklarından izole edilen Aspergillus fumigatus 2101 suşundan elde edildi. PL, amonyum sülfat çöktürmesi, jel filtrasyon ve iyon değişim kromatografisi kullanılarak saflaştırıldı. Bu saflaştırma basamaklarından sonra, 12.4 saflaştırma katsayısı elde edildi. PL'nin optimum pH ve sıcaklığı sırasıyla 8.0 ve $40^{\circ} \mathrm{C}^{\prime}$ de 70 dakikadır. PL'nin molekül ağırlığı 11.5 kDa'dur. Sıvı besi ortamında maksimum PL aktivitesi meyve pulpları ile elde edilmiştir. Stabilite deneyleri, PL'nin $4^{\circ} \mathrm{C}^{\prime}$ de 20 aya kadar kararlı olduğunu göstermiştir. En yüksek PL aktivitesi karbon kaynağı olarak sitrus pectin kullanıldığında elde edilmiştir. PL, $\mathrm{FeSO}_{4}, \mathrm{FeCl}_{3}$ ve askorbik asit tarafından güçlü bir şekilde aktive edilmiştir.

Anahtar Kelimeler

Pektin liyaz, Aspergillus, kromatografi, inhibisyon, iyonlar.

Article History: Received: Jan 8, 2016; Revised: Mar 16, 2016; Accepted: Mar 20, 2016; Available Online: Apr 01, 2016. Dol: 10.15671/HJBC.20164417567

Correspondence to: İ. Özmen, Department of Chemistry, Suleyman Demirel University, Isparta, Turkey. 


\section{INTRODUCTION}

Dectin is complex colloidal acid polysaccharide presents in plant primary cell wall and middle lamella [1]. Pectin includes homogalacturonan(HG), xylogalacturonan (XGA) rhamnogalacturonan I (RG I), rhamnogalacturonan II (RG II) parts. HG is the smooth region of the pectin, it consists $\alpha-1,4-D$-galacturonic acid residues. XGA includes $\beta$-1,3-D-xylose residues which are linked to galacturonyl residues of HG. $\alpha$-1,2-rhamnosyl and galactosyluronic acid residues are present in RG I parts of pectin. RG II includes approximately nine $\alpha-1,4-D$-galactosyluronic acid residues. XGA, RG I, RG II form hairy region of the pectin [2-4].

Pectinases are upcoming enzymes and among the first enzyme groups used in homes [5]. Pectinases are produced by many microorganisms such as bacteria, yeast, fungi and plants [6]. Aspergillus and Penicillium genus are preferred for industrial applications [7] Pectinase is general name used for enzymes that catalyze hydrolysis of glycosidic bonds in pectin polysaccharides [8]. Pectinases can be divided 3 major groups: protopectinase, pectinesterases, depolymerizing enzymes [5].

Protopectinase solubilizes protopectin and constitutes highly polymerized soluble pectin. Pectinesterases catalyze removal of methoxyl group from pectin [5]. Depolymerizing enzymes are divided 2 sub-groups: hydrolases and lyases. Hydrolases consist of endo- and exopolygalacturonase. Lyases include endo-, exopectate lyase and endo-pectin lyase (endo-PL) [9].

The objective of this study is to produce of endopectin lyase in submerged culture medium from Aspergillus fumigatus strain 2101 isolated from local water sources. Effects of waste materials, for maximum $\mathrm{PL}$ production in submerged culture were investigated. Purification studies with ammonium sulphate, chromatographic techniques and characterization studies of $\mathrm{PL}$ were also performed. Effects of metal ions and several chemicals were determined. Stability tests of $\mathrm{PL}$ were carried out at $4^{\circ} \mathrm{C}$.

\section{MATERIALS AND METHOD}

\section{Chemicals and Reagents}

Citrus pectin, yeast extract, DEAE-cellulose, Sephadex G-100 and Coomassie Brillant Blue were purchased from Sigma-Aldrich. Ethyl alcohol, $\mathrm{Na}_{2} \mathrm{HPO}_{4}, \mathrm{NaCl}, \mathrm{HCl},\left(\mathrm{NH}_{4}\right)_{2} \mathrm{SO}_{4}$ were purchased from Merck. All chemicals were analytical grade. Aspergillus fumigatus strain 2101 was procured Adnan Menderes University Arts and Science Faculty, Department of Biology, Section of Molecular Biology.

\section{Identification of Fungi}

In our study, DNA isolation was made by classical phenol chloroform method. Purity and concentration measurements were made by nonodrop spectrophotometer (Thermo). PCR reactions were carried out at $95^{\circ} \mathrm{C} 5 \mathrm{~min}, 35$ cycle with $94^{\circ} \mathrm{C} 1 \mathrm{~min}, 55^{\circ} \mathrm{C} 1 \mathrm{~min}$ and $72^{\circ} \mathrm{C}$ min, and then $72^{\circ} \mathrm{C} 7 \mathrm{~min}$. $5 \mathrm{X}$ Firepol Master Mix was used in reactions with ITS primers. Electrophoresis was made in agarose gel (1.2\%). For sequencing, samples were sent to Macrogen Europe. Sequence data was processed with Blastn. Sequence alignment and neighbour joining tree construction was made by using MEGA 6.06 software. For aligning sequences ClustalW was used which was in MEGA software.

\section{Culture Conditions of Fungi}

Aspergillus fumigatus strain 2101 was isolated from local water sources in Aydın, Turkey and it was used for PL production. First of all, Aspergillus fumigatus strain 2101 was grown on potato dextrose agar and incubated at $35^{\circ} \mathrm{C}$ for 7 days. It was stored at $-80^{\circ} \mathrm{C}$ for further usage. Submerged culture for PL production was prepared according to Sandri method with some modifications [10].

\section{Maximum Enzyme Production with Waste Materials}

For maximum enzyme production, different waste materials were used as carbon sources. Apricot, apple, peach, sour cherry were used as fruit pulps. Fruit pulps (I), wheat bran (II), fruit pulps+wheat bran (III) and citrus pectin (IV) were added different flask cultures and incubation 
was performed in rotating shaker. Crude enzyme was taken every flask, centrifuged and enzyme activity was measured. The best carbon source and optimum time for enzyme production in submerged culture were determined between 6-168 hours.

\section{Enzyme Purification Steps}

Flask was taken from rotating shaker when incubation time ended. Centrifugation was carried out at $8000 \mathrm{rpm}$ for $25 \mathrm{~min}$. After centrifugation, crude enzyme was partially purified with $\left(\mathrm{NH}_{4}\right)_{2} \mathrm{SO}_{4}$. Precipitation was carried out between $0-95 \%$ ranges. Then, gel filtration column $(1 \times 15$ $\mathrm{cm})$ was pre-equilibrated with phosphate buffer (0.05 M, pH 8.0) and 0-95\% precipitates were loaded on to column. Elution was performed with the same buffer and enzyme was pooled. Ion-exchange column was pre-equilibrated and pooled enzyme taken from gel filtration column was loaded on to ion-exchange column $(1 \times 15 \mathrm{~cm})$ with 1.5 and $2.0 \mathrm{M} \mathrm{NaCl}$ gradient. Elution was performed with phosphate buffer $(0.05 \mathrm{M}, \mathrm{pH}$ 8.0) and fractions were collected and pooled. After every purification steps, enzyme activity and protein amounts of PL were measured.

\section{PL Activity Tests}

PL activity was performed according to Albersheim methods with some modifications [11]. Optical density of 4,5-unsaturated oligogalacturonides were measured at $235 \mathrm{~nm}$ with UV-vis spectrophotometers (Shimadzu, UVmini-1240 Spectrophotometers). Enzyme activity was defined in terms of $\mu$ mole unsaturated 4,5-oligogalacturonides released per $\min$ and molar extinction coefficient value of the product was used as $5550 \mathrm{M}^{-1} \mathrm{~cm}^{-1}$. All experiments were carried out triplicate.

\section{Molecular Weight Determination of PL}

Molecular weight of $\mathrm{PL}$ and its purity were determined with SDS-PAGE gel electrophoresis method. $12 \%$ resolving gel and $5 \%$ stacking gel were used. The electrophoresis was run $30 \mathrm{~min}$ at $50 \mathrm{~V}$ and $200 \mathrm{~min}$ at $100 \mathrm{~V}$. After running, methanol $(50 \%,(v / v))$, Coomassie Brillant Blue
R-250 (0.1\% (w/v)) and acetic acid (50\%, (v/v)) were used for staining. Destaining was performed with the same solution used for staining without Coomassie Brillant Blue $[12,13]$.

\section{Protein Determination}

Protein concentration was determined according to Bradford method, bovine serum albumin (BSA) was used as the standard [14]. All experiments were carried out triplicate.

\section{Determination of Optimum $\mathrm{pH}$ and Temperature} Citrate-phosphate buffer ( $\mathrm{pH}$ 4.0-6.0), phosphate buffer $(\mathrm{pH}$ 6.0-8.0) and carbonate buffer $(\mathrm{pH}$ 8.0-9.0) were used with $0.05 \mathrm{M}$ concentration. Optimum $\mathrm{pH}$ for $\mathrm{PL}$ was determined with these buffer solutions.

To determine optimum temperature and time for $\mathrm{PL}$, the experiments were carried out between $40-100^{\circ} \mathrm{C}$ with different time intervals (to 100 from $10 \mathrm{~min}$ ). All experiments were carried out triplicate.

\section{Effects of Chemical Substances on PL Activity} Effects of chemical substances on PL such as $\mathrm{BaCl}_{2}, \mathrm{HgCl}, \mathrm{ZnSO}_{4^{\prime}} \mathrm{FeCl}_{3^{\prime}} \mathrm{FeSO}_{4^{\prime}}$ EDTA, $\mathrm{CaC}_{12^{\prime}}$ $\mathrm{CoCl}_{2}, \mathrm{LiCl}_{3}, \mathrm{MgCl}_{2}, \mathrm{MgSO}_{4}, \mathrm{NaF}, \mathrm{K}_{4}\left[\mathrm{Fe}(\mathrm{CN})_{6}\right], \mathrm{KCl}$, $\mathrm{KMnO}_{4}, \mathrm{NaN}_{3}, \mathrm{NaCl}$, ascorbic acid, glycine, SDS, L-Cysteine, citric acid monohydrate, $\mathrm{NaH}_{2} \mathrm{AsO}_{4}$, Triton X-100, $\left(\mathrm{NH}_{4}\right)_{2} \mathrm{SO}_{4}$, L-Arginine monohydrate, L-Asparagine were determined. All experiments were carried out triplicate.

\section{Storage Tests of PL}

Purified enzyme was stored in refrigerator at $4{ }^{\circ} \mathrm{C}$ for 98 days. $500 \mu \mathrm{L}$ PL was taken at special time ranges and enzyme activity was measured.

\section{Substrate Specificity Tests of PL}

To perform substrate specificity of $\mathrm{PL}$ against citrus pectin, peptone and PDA; substrate solutions were prepared. Enzyme was incubated with these substrates at $40^{\circ} \mathrm{C} 40 \mathrm{~min}$. Substrate preference of PL was determined. 


\section{AATTCACTCTCCTCCGGCATCGATCGAGGTCACCTTAGAAAATAAAGTTGGGTGTCGGCT GGCGCCGGCCGGGCCTACAGAGCAGGTGACAAAGCCCCATACGCTCGAGGACCGGACGC GGTGCCGCCGCTGCCTTTCGGGCCCGTCCCCCGGGAGAGGGGGACGGGGGCCCAACACA CAAGCCGTGCTTGAGGGCAGCAATGACGCTCGGACAGGCATGCCCCCCGGAATACCAGG GGGCGCAATGTGCGTTCAAAGACTCGATGATTCACTGAATTCTGCAATTCACATTACTTAT CGCATTTCGCTGCGTTCTTCATCGATGCCGGAACCAAGAGATCCGTTGTTGAAAGTTTTAA CTGATTACGATAATCAACTCAGACTGCATACTTTCAGAACAGCGTTCATGTTGGGGTCTTC GGCGGGCGCGGGCCCGGGGGCGCAAGGCCTCCCCGGCGGCCGTCGAAACGGCGGGCCCG CCGAAGCAACAAGGTACGATAGACACGGGTGGGAGGTTGGACCCAGAGGGCCCTCACTC GGTAATGATCCTTCCGCAGGTCCCCTAACGGAAGGGTCATTCCCGAG}

Figure 1. Nucleotide sequence of Aspergillus fumigatus strain 2101.

\section{RESULTS AND DISCUSSION}

\section{Nucleotide Sequence of Aspergillus fumigatus Strain 2101}

According to phylogenetic tree of our microorganism, fungus studied in this report was defined as Aspergillus fumigatus strain 2101 and Figure 1 shows that nucleotide sequence of Aspergillus fumigatus strain 2101.

\section{Maximum Enzyme Production with Waste Materials}

To recycle and reuse of waste materials, fruit pulps (I), wheat bran (II), fruit pulps+wheat bran (III) and citrus pectin (IV) were used as a carbon source in submerged culture media for enzyme production. The weight of fruit pulps in all submerged culture media was taken in equal amounts. PL showed maximum activity in submerged culture which included fruit pulps whereas submerged culture medium contained citrus pectin gave the lowest enzyme activity values. So, fruit pulps (I) were the best carbon sources in submerged culture media for PL production. After this submerged culture media optimization with carbon sources, we used fruit pulps in all submerged cultures (Figure 2).

\section{Enzyme Purification}

$\mathrm{PL}$ was purified with three steps. It was partially purified with $\left(\mathrm{NH}_{4}\right)_{2} \mathrm{SO}_{4}$ fractionation. Then, $\mathrm{PL}$ was purified with gel filtration and ion-exchange chromatography. It was obtained 12.4 purification fold, after 3 steps purification. Purification steps of $\mathrm{PL}$ are shown in Table 1.

\section{Molecular Weight Determination of PL}

The homogeneity of PL was validated by SDSPAGE electrophoresis. Molecular weight of PL was determined by plotting log of molecular weight of markers versus their $\mathrm{Rf}$ values. Molecular weight of PL was found $11.5 \mathrm{kDa}$ (Figure 3).

In previous studies, molecular mass of $\mathrm{PL}$ secreted by Penicillium italicum was 22 kDA [21]. Molecular weight of PL from Bacillus sp. DT7 was $106 \mathrm{kDa}[21,22]$. Molecular weight of PL secreted by Aspergillus flavus was $38 \mathrm{kDa}$ [23]. PLoverproducing hybrid was obtained by protoplast fusion between mutant pectinolytic Aspergillus flavipes and Aspergillus niveus $\mathrm{CH}-\mathrm{Y}-1043$ had 30 kDa molecular weight [19].

\section{Optimum pH and Temperature}

$\mathrm{PL}$ showed activity between $\mathrm{pH}$ 4.0-9.0 with different buffers. PL had maximum activity at pH 8.0 with phosphate buffer. PL also gave high activity values at $\mathrm{pH} 6.0$ and $\mathrm{pH} 7.0$ with phosphate buffer and their results were similar with $\mathrm{pH}$ 8.0. $\mathrm{PL}$ gave low activity values at $\mathrm{pH} 4.0$ and 8.0 with citrate-phosphate and carbonate buffers, respectively. $\mathrm{PL}$ produced in our laboratory can be used at industrial scale with wide $\mathrm{pH}$ ranges 


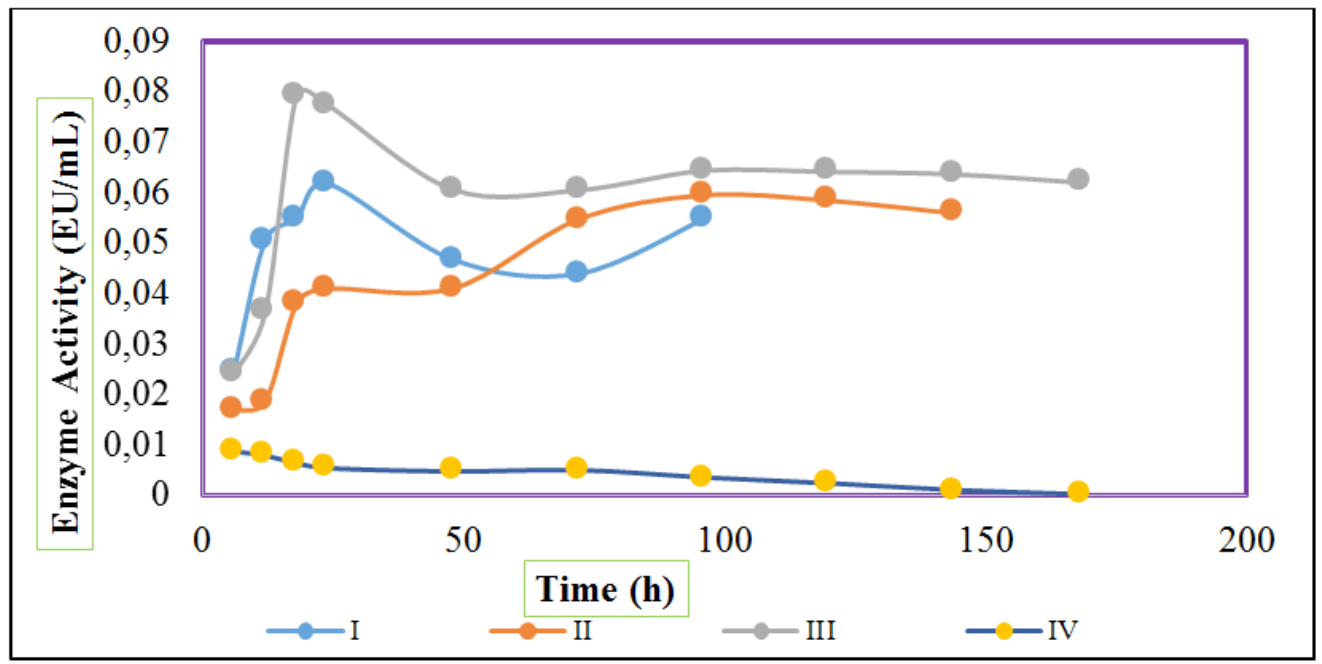

Figure 2. Effects of waste materials on PL activity in submerged culture medium (fruit pulps + wheat bran (I), wheat bran (II), fruit pulps (III) and citrus pectin (IV)).

Table 1. Purification steps of PL secreted by Aspergillus fumigatus strain 2101.

\begin{tabular}{|c|c|c|c|c|}
\hline Purification steps & $\begin{array}{l}\text { Total activity } \\
\text { (EU/ml) }\end{array}$ & Total protein & $\begin{array}{l}\text { Specific Activity } \\
\text { (EU/mg) }\end{array}$ & Purification fold \\
\hline Crude Extract & 0.07 & 0.98 & 0.071 & 1 \\
\hline $\begin{array}{l}\text { Ammonium } \\
\text { sulphate } \\
\text { precipitation } \\
(0-95 \%)\end{array}$ & 0.81 & 6.30 & 0.13 & 1.83 \\
\hline $\begin{array}{c}\text { Gel filtration } \\
\text { chromatography }\end{array}$ & 0.52 & 2.26 & 0.23 & 3.24 \\
\hline $\begin{array}{l}\text { Ion-exchange } \\
\text { chromatography }\end{array}$ & 0.39 & 0.44 & 0.88 & 12.4 \\
\hline
\end{tabular}

( $\mathrm{pH}$ 4.0-9.0). Optimum $\mathrm{pH}$ results of $\mathrm{PL}$ are demonstrated in Figure 4. PL lost its activity in citrate-phosphate buffer for $\mathrm{pH} 4.0$; 5.0; 6.0; $41.10 \%, 9.53 \%, 15.96 \%$; in phosphate buffer for pH 6.0; 7.0; 5.51\%; 9.53\%; in carbonate buffer for pH 8.0; 9.0; 48.31\%; 4.24\%, respectively.

$\mathrm{PL}$ showed activity between 40 to $90^{\circ} \mathrm{C}$ and had maximum activity at $40^{\circ} \mathrm{C}$ for $70 \mathrm{~min}$, at $50^{\circ} \mathrm{C}$ for $10 \mathrm{~min}$, at $60^{\circ} \mathrm{C}$ for $30 \mathrm{~min}$, at $70^{\circ} \mathrm{C}$ for $30 \mathrm{~min}$, at $80^{\circ} \mathrm{C}$ for $10 \mathrm{~min}$, at $90^{\circ} \mathrm{C}$ for $10 \mathrm{~min}$. The enzyme obtained in this study showed activity at $90^{\circ} \mathrm{C}$ till $100 \mathrm{~min}$ and didn't lose its activity largely as far as $100 \mathrm{~min}$ at $80^{\circ} \mathrm{C}$. It also showed high activity values at $50^{\circ} \mathrm{C}$. Optimum temperature results of $\mathrm{PL}$ are shown in Figure 5.
In the literature, PL secreted by Debaryomycesflavus nepalensis had maximum activity at $\mathrm{pH} 6.4$ [24]. Pectinase from Streptomyces sp.-QG-11-3 was optimally active at pH 3.0 in citrate-phosphate buffer and it retained more than $85 \%$ its activity between $\mathrm{pH} 2.0$ to 9.0 [25].

In the previous studies, maximum PL activity was obtained at $35^{\circ} \mathrm{C}$ from Debaryomycesflavus nepalensis [24]. PL from Penicillium italicum completely inactivated after $10 \mathrm{~min}$ at $80^{\circ} \mathrm{C}$ [26]. Paenibacillus amylolyticus endophytic strain had maximum $\mathrm{PL}$ activity at $40^{\circ} \mathrm{C}$ and $\mathrm{pH} 7.9$ [20]. $\mathrm{PL}$ secreted by Aspergillus sp. $\mathrm{CH}-\mathrm{Y}-1043$ showed maximum activity at $\mathrm{pH}$ and temperature values 8.5-8.8 and $40-45^{\circ} \mathrm{C}$, respectively [2]. Optimum 


\section{$70 \mathrm{kDa}$ \\ 55 kDa \\ 35 kDa \\ 25 kDa}

15 kDa

\section{$10 \mathrm{kDa}$}

Figure 3. SDS-PAGE analysis of purified PL. Lane 1 marker, Lane 2, 3 pooled PL after ion-exchange chromatography.

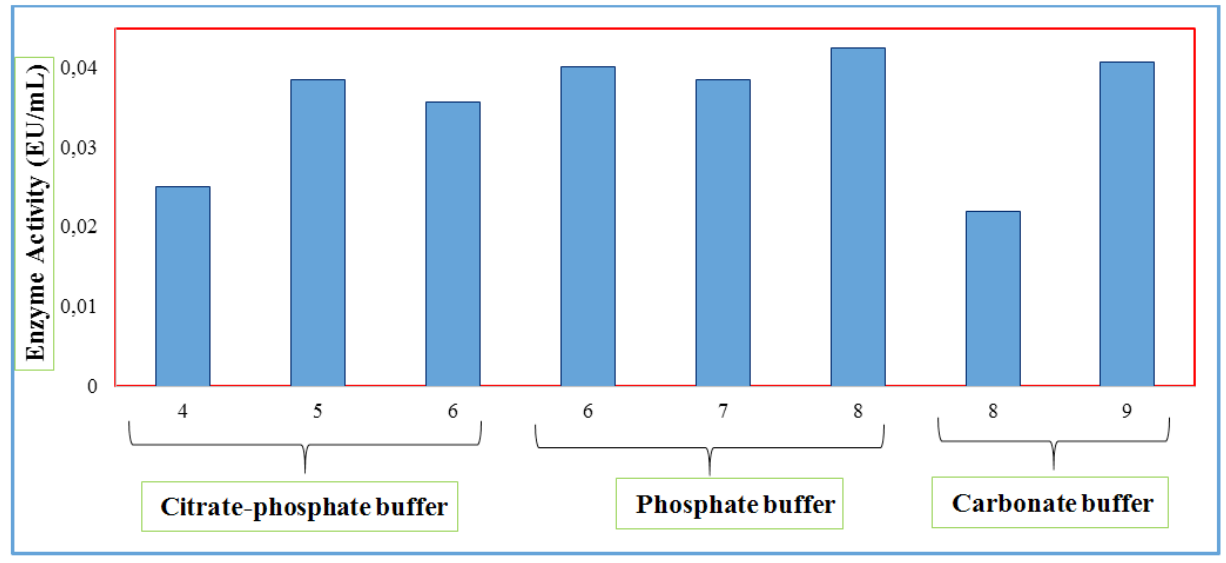

Figure 4. $\mathrm{pH}$ results of $\mathrm{PL}$ between $\mathrm{pH}$ 4.0-9.0.

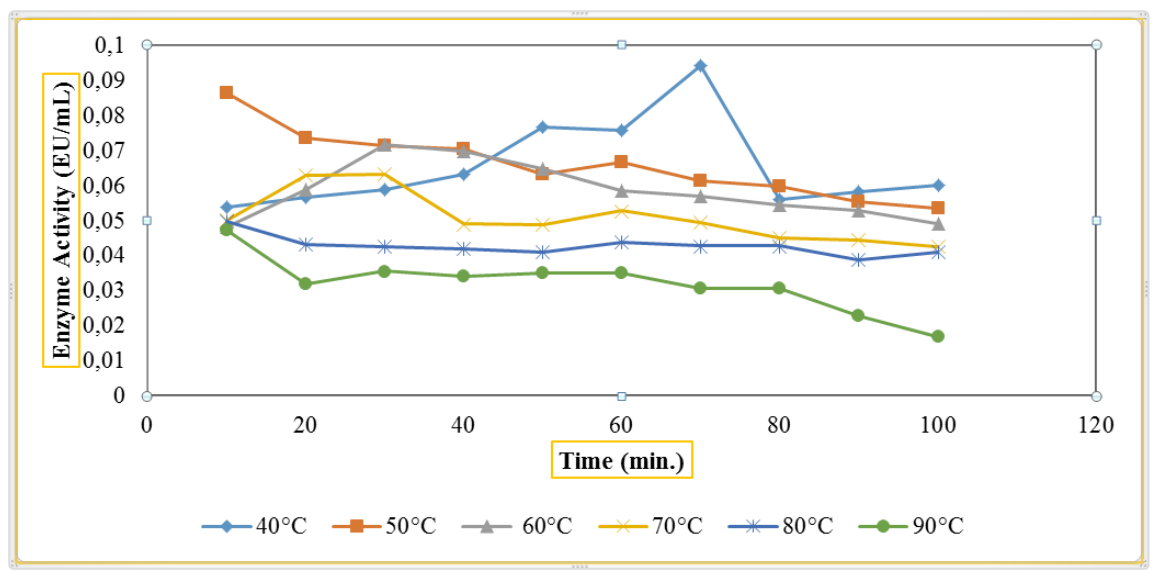

Figure 5. PL activity at different temperatures between 10 to 100 minutes. 


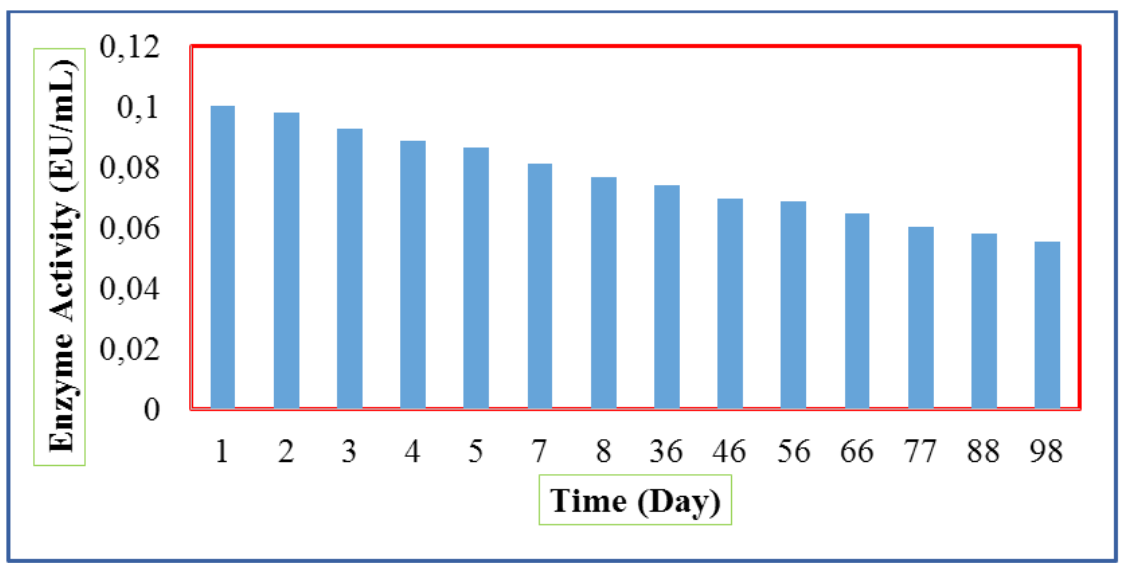

Figure 6. Storage results of $\mathrm{PL}$ at $4^{\circ} \mathrm{C}$.

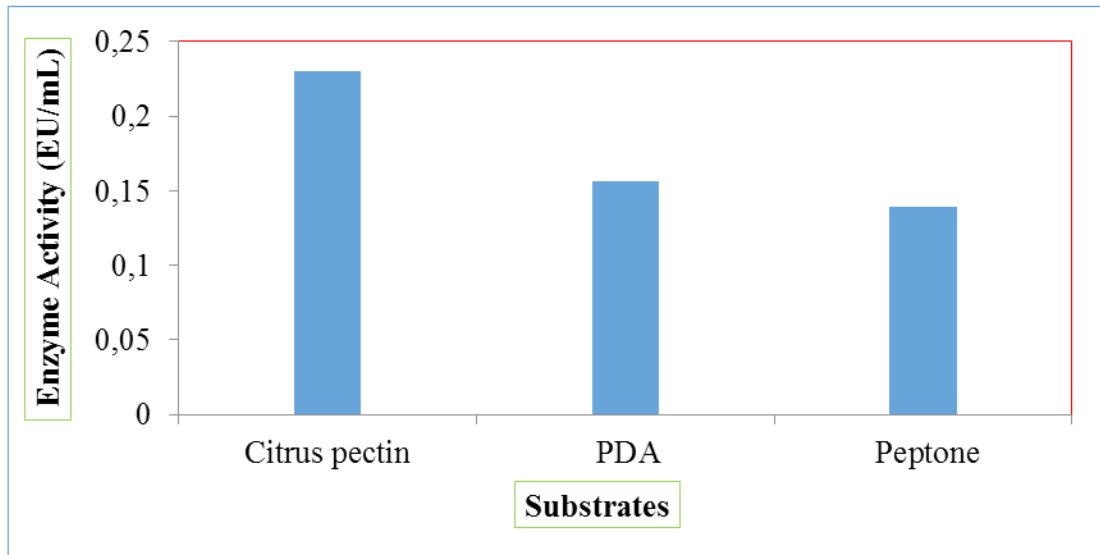

Figure 7. Substrate specificity results of PL.

$\mathrm{pH}$ and temperature for recombinant $\mathrm{PL}$ from a Penicillium purpurogenum was 6.0 (Mcllvaine buffer ( $0.1 \mathrm{M}$ citric acid/0.2 M disodium hydrogen phosphate) and $50^{\circ} \mathrm{C}$, respectively [27].

\section{Storage Results of PL}

To determine storage stability of $\mathrm{PL}$ at $4^{\circ} \mathrm{C}$, it was stored in refrigerator. PL lost $32 \%$ of its starting activity at 98 days. At the end of 20 months, the $\mathrm{PL}$ conserved $60 \%$ of its activity. Storage results of $\mathrm{PL}$ are shown in Figure 6.

\section{Substrate Specificity Results of PL}

Substrate specificity results of $\mathrm{PL}$ against citrus pectin, peptone and PDA were graphed in Figure 7. $\mathrm{PL}$ gave the best result against citrus pectin as a substrate.

In the literature, PL from Paenibacillus amylolyticus was used for substrate specificity tests. Citrus pectin, apple pectin, polygalacturonic acid were used as a substrate and PL was more active on citrus pectin than other substrates [20].

\section{Effects of Chemical Substances on PL Activity}

Effects of metal ions $\mathrm{BaCl}_{2^{\prime}} \quad \mathrm{HgCl}, \mathrm{ZnSO}_{4^{\prime}}$ $\mathrm{FeCl}_{3} \cdot 6 \mathrm{H}_{2} \mathrm{O}, \quad \mathrm{FeSO}_{4^{\prime}} \mathrm{CaCl}_{2^{\prime}} \mathrm{CoCl}_{2^{\prime}} \mathrm{LiCl}_{3^{\prime}} \quad \mathrm{MgCl}_{2^{\prime}}$ $\mathrm{MgSO}_{4}, \quad \mathrm{NaF}, \quad \mathrm{K}_{4}\left[\mathrm{Fe}(\mathrm{CN})_{6}\right], \quad \mathrm{KCl}, \quad \mathrm{KMnO}_{4}, \mathrm{NaN}_{3^{\prime}}$ $\mathrm{NaCl}$; amino acids and the other chemicals were summarized in Table 2. PL activity was reached up $306.192 \%$ at $6.0 \times 10^{-3} \mathrm{M}$ concentration with $\mathrm{BaCl}_{2}, 655,39 \%$ at $1.33 \times 10^{-3} \mathrm{M}$ concentration with $\mathrm{HgCl}_{1} 1108.68 \%$ at $6.0 \times 10^{-3} \mathrm{M}$ concentration with $\mathrm{FeCl}_{3}, 840.10 \%$ at $4.0 \times 10^{-3} \mathrm{M}$ concentration with $\mathrm{FeSO}_{4}, 488.91 \%$ at $6.0 \times 10^{-3} \mathrm{M}$ concentration with $\mathrm{K}_{4}\left[\mathrm{Fe}(\mathrm{CN})_{6}\right], 407.2 \%$ at $5.33 \times 10^{-3} \mathrm{M}$ concentration with ascorbic acid; $707.90 \%$ at $1.33 \times 10^{-3} \mathrm{M}$ concentration with glycine, $172,43 \%$ at $1.33 \times 10^{-3}$ $M$ concentration with Triton $X-100$. Activation and inhibition effects of metal ions and the other chemicals on PL activity are demonstrated in Table 2 and Figure 8. 

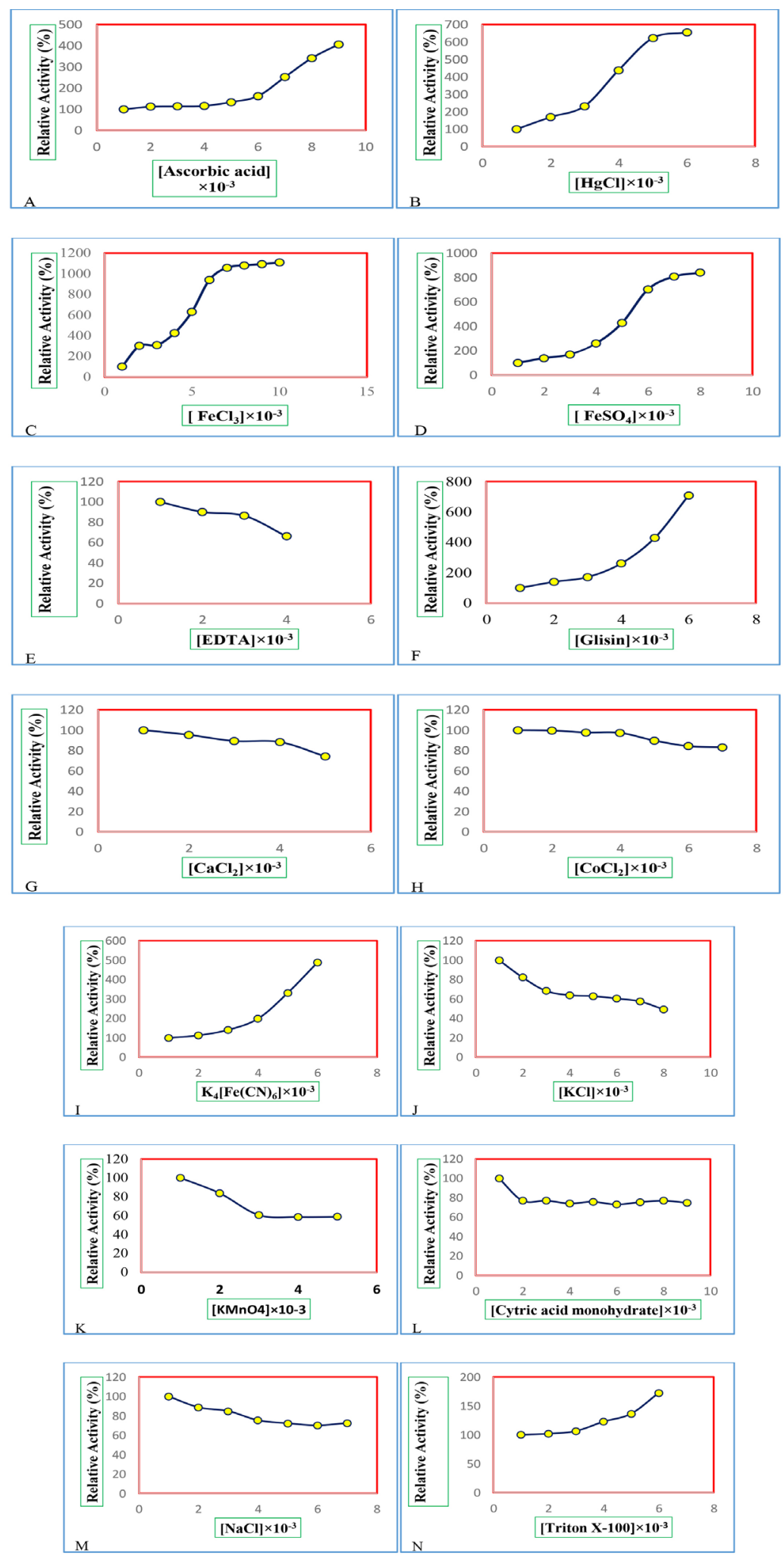

Figure 8. Effects of metal ions, amino acids and several chemicals on $\mathrm{PL}$ activity A) ascorbic acid B) $\mathrm{HgCl} \mathrm{C)} \mathrm{FeCl}{ }_{3} \mathrm{D}$ ) $\mathrm{FeSO}_{4}$ E) EDTA F) glycine G) $\mathrm{CaCl}_{2} \mathrm{H}$ ) $\left.\left.\mathrm{CoCl}_{2} \mathrm{I}\right) \mathrm{K} 4\left[\mathrm{Fe}(\mathrm{CN})_{6}\right] \mathrm{J}\right) \mathrm{KCl} \mathrm{K}$ ) $\mathrm{KMnO}_{4}$ L) citric acid monohydrate M) $\mathrm{NaCl} N$ ) Triton $\mathrm{X}-100$. 
Table 2. Effects of chemical substances on PL activity.

\begin{tabular}{|c|c|c|c|c|}
\hline Chemicals & In this study & $\begin{array}{c}\text { Relative Activity } \\
(\%)\end{array}$ & Concentration (M) & Previous studies \\
\hline \multicolumn{5}{|l|}{ Metal ions } \\
\hline $\mathrm{BaCl}_{2}$ & activation & 249.02 & up to 5.33 & \\
\hline $\mathrm{HgCl}$ & activation & 623.09 & up to 0.67 & \\
\hline $\mathrm{ZnSO}_{4}$ & no effect & & - & $\begin{array}{c}\text { Inhibition } \\
{[20,23,28,]} \\
\text { Activation [29] }\end{array}$ \\
\hline $\mathrm{FeCl}_{3} \cdot 6 \mathrm{H}_{2} \mathrm{O}$ & activation & 1059.41 & up to 2.67 & \\
\hline $\mathrm{FeSO}_{4}$ & activation & & up to 1.33 & \\
\hline $\mathrm{CaCl}_{2}$ & inhibition & 703.16 & up to 0.333 & Inhibition $[20,23]$ \\
\hline $\mathrm{CoCl}_{2}$ & inhibition & 88.30 & up to 0.67 & $\begin{array}{l}\text { Inhibition } \\
{[20,25,28]}\end{array}$ \\
\hline $\mathrm{LiCl}_{3}$ & no effect & 89.84 & - & \\
\hline $\mathrm{MgCl}_{2}$ & no effect & & - & \\
\hline $\mathrm{MgSO}_{4}$ & no effect & & - & \\
\hline $\mathrm{NaF}$ & no effect & & - & \\
\hline $\mathrm{K}_{4}\left[\mathrm{Fe}(\mathrm{CN})_{6}\right]$ & activation & 198.82 & up to 0.333 & Inhibition $[20,23]$ \\
\hline $\mathrm{KCl}$ & inhibition & 57.51 & up to 2.67 & $\begin{array}{l}\text { Inhibition } \\
{[20,25,28]}\end{array}$ \\
\hline $\mathrm{KMnO}_{4}$ & inhibition & 60.52 & up to 0.133 & \\
\hline $\mathrm{NaN}_{3}$ & no effect & & - & \\
\hline $\mathrm{NaCl}$ & inhibition & 75.48 & up to 0.333 & \\
\hline \multicolumn{5}{|l|}{ other chemicals } \\
\hline Ascorbic acid & activation & 162.90 & up to 1.33 & Inhibition [25] \\
\hline Glycine & activation & 171.29 & up to 0.133 & \\
\hline SDS & inhibition & 97.03 & up to 0.333 & \\
\hline L-Cysteine & no effect & & - & \\
\hline $\begin{array}{l}\text { Citric acid } \\
\text { monohydrate }\end{array}$ & inhibition & 75.57 & up to 4.0 & $\begin{array}{c}\text { Inhibition } \\
{[23,25,28,29,30]}\end{array}$ \\
\hline $\mathrm{NaH}_{2} \mathrm{AsO}_{4}$ & no effect & & - & \\
\hline Triton X-100 & activation & 136.38 & up to 0.67 & \\
\hline EDTA & inhibition & 86.36 & up to 0.333 & $\begin{array}{c}\text { No effect [31] } \\
\text { Activation [20] }\end{array}$ \\
\hline$\left(\mathrm{NH}_{4}\right)_{2} \mathrm{SO}_{4}$ & no effect & & Inhibition [25] & \\
\hline $\begin{array}{l}\text { L-Arginine } \\
\text { monohydrate }\end{array}$ & no effect & - & & \\
\hline L-Asparagine & no effect & - & & \\
\hline
\end{tabular}




\section{References}

1. J.N. Be Miller, An introduction to pectins: Structure and properties, In Fishman, M.L., \& Jem, J (Eds.), Chemistry and Functions of Pectins, ACS Symposium Series 310. American Chemical Society, Washington, DC, (1986).

2. L. Delgado, B.A. Trejo, C. Huitrón, G. Aguilar, Pectin lyase from Aspergillus sp. CH-Y-1043, Applied Microbiology Biotechnology, 39 (1992) 515-519.

3. R.P. De Vries, and J. Visser, Aspergillus enzymes involved in degradation of plant cell wall polysaccharides, Microbiology and Molecular Biology Reviews, 65 (2001) 497-552.

4. A. Martínez-Trujillo, J.S. Aranda, C. Gómez-Sánchez, B. Trejo-Aguilar, G. Aguilar-Osorio, Constitutive and inducible pectinolytic enzymes from Aspergillus flavipes FP-500 and their modulation by $\mathrm{pH}$ and carbon source, Brazilian Journal of Microbiology, 40 (2009) 40-47.

5. D.R. Kashyap, P.K. Vohra, S. Chopra, R. Tewari, Applications of pectinases in the commercial sector: a review, Bioresource Technology, 77 (2001) 215-227.

6. R.S.S. Jayani, S. Saxena, R. Gupta, Microbial pectinolytic enzymes: A review. Process Biochemistry, 40 (2005) 2931-2944.

7. S.R. Nair, S.K. Rakshit, T. Panda, Effect of carbon sources on the synthesis of pectinase by Aspergilli, Bioprocess Engineering, 13 (1995) 37-40.

8. I.Reid, andM.Ricard, Pectinase in papermaking:solving retention problems in mechanical pulps bleached with hydrogen peroxide, Enzyme and Microbial Technology, 26 (2000) 115-123.

9. S. Yadav, P.K. Yadav, D. Yadav, K.D.S. Yadav, Pectin Iyase: A review, Process Biochemistry, 44 (2009) 1-10.

10. I.G. Sandri, R.C. Fontana, D.M. Barfknecht, M.M. Silveira, Clarification of fruit juices by fungal pectinases, LWT-Food Science and Technology, 44 (2011) 2217-2222.

11. P. Albersheim, Pectin lyase from fungi, Methods in Enzymology, 8 (1966) 628-631.

12. U.K. Laemmli, Cleavage of structural proteins during the assembly of the head of Bacteriophage T4, Nature, 15 (1970) 680-685.

13. G. Temizkan, S. Yılmazer, M. Ozturk, S. Arı, H. Ertan, A. Topal-Sarıkaya, N. Arda, Moleküler Biyolojide Kullanılan Yöntemler. In: G Temizkan \& N Arda (Eds.), Proteinlerin İzolasyonu, Analizi, Saflaştırılması, (2008) (pp. 161-273). İstanbul, Turkey.

14. M.M. Bradford, A rapid and sensitive method for the quantitation of microgram quantities of protein utilizing the principle of protein-dye binding, Analytical Biochemistry, 72 (1976) 248-254.

15. D. Silva, E.S. Martins, R. Silva, E. Gomes, Pectinase production by Penicillium viridicatum RFC3 by solid state fermentation using agricultural wastes and agro-industrial by-products, Brazilian Journal of Microbiology, 33 (2002) 318-324.
16. N. Martin, S.R. Souza, R. Silva, E. Gomes, Pectinase production by fungal strains in solid-state fermentation using agro-industrial bioproduct, Brazilian Archives of Biology and Technolgy, 47 (2004) 813-819.

17. A. Alaña, A. Gabilondo, F. Hernando, M.D. Moragues, J.B. Domínguez, M.J. Ilama, J.L. Serra, Pectin Lyase Production by a Penicillium italicum strain, Applied and Environmental Microbiology, 55 (1989) 1612-1616.

18. S. Koser, Z. Anwar, Z. Iqbal, A. Anjumc, T. Aqil, S. Mehmood, M. Irshada, Utilization of Aspergillus oryzae to produce pectin lyase from various agroindustrial residues, $J$ of Radiation Research and Applied Sciences, 7 (2014) 327-332.

19. S. Solís, J. Loeza, G. Segura, J. Tello, N. Reyes, P. Lappe, L. Guitérrez, F. Ríos, C. Huitrón, Hydrolysis of orange peel by a pectin lyase-overproducing hybrid obtained by protoplast fusion between mutant pectinolytic Aspergillus flavipes and Aspergillus niveus $\mathrm{CH}-\mathrm{Y}-1043$, Enzyme and Microbial Techology, 44 (2009) 123-128.

20. C.C.H. Sakiyama, E.M. Paula, P.C. Pereira, A.C. Borges, D.O. Silva, Characterization of pectin lyase produced by an endophytic strain isolated from coffee cherries, Letters in Applied Microbiology, 33 (2001) 117-121.

21. A. Alaña, I. Alkorta, J.B. Domínguez, M.J. Llama, J.L. Serra, Pectin lyase activity in a Penicillium italicum strain, Applied Environmental Microbiology, 56 (1990) 3755-3759.

22. D.R. Kashyap, S. Chandra, A. Kaul, R. Tewari, Production, purification and characterization of pectinase from a Bacillus sp. DT7, World Journal of Microbiology and Biotechnology, 16 (2000) 277-282.

23. S. Yadav, P.K. Yadav, D. Yadav, K.DS. Yadav, Purification and characterization of an alkaline pectin lyase from Aspergillus flavus, Process Biochemistry, 43 (2008) 547-552.

24. S.N. Gummadi, and D.S. Kumar, Optimization of chemical and physical parameters affecting the activity of pectin lyase and pectatelyase from Debaryomycesflavusnepalensis: A statistical approach, Biochemical Engineering Journal, 30 (2006) 130-137.

25. Q.K. Beg, B. Bhushan, M. Kapoor, G.S. Hoondal, Production and characterization of thermostable xylanase and pectinase from Streptomyces sp. QG-113, Journal of Industrial Microbiology \& Biotechnology, 24 (2000) 396-402.

26. A. Alaña, M.J. Llama, J.L. Serra, Purification and some properties of the pectin lyase from Penicillium italicum, FEBS Letters, 280 (1991) 335-340.

27. C. Perez-Fuentes, M.C. Ravanal, J.H. Eyzaguirre, Heterologous expression of a Penicillium purpurogenum pectin lyase in Pichia pastoris and its characterization, Fungal Biology, 118 (2014) 507-515.

28. S.H. Hamdy, Purification and characterization of the pectin lyase produced by Rhizopus oryzae grown on orange peels, Annals of Microbiology, 55 (2005). 205-211. 
29. S. Yadav, A.K. Dubey, G. Anand, R. Kumar, D. Yadav, Purification and biochemical characterization of an alkaline pectin lyase from Fusarium decemcellulare MTCC 2079 suitable for Crotolaria juncea fiber retting, Journal of Basic Microbiology, 53 (2013) 1-9.

30. A. Losonczi, E. Csisza'r, G. Szaka'cs, L. Bezur, Role of the EDTA chelating agent in bioscouring of cotton, Textile Research Journal, 75 (2005). 411-417.
31. W.C. Chen, E.C. Hsieh, T.C. Tseng, Purification and characterization of a pectin lyase from Pythium splendens infected cucumber fruits, Botanical Bulletin Academia Sinica, 39 (1998) 81-186. 
